\title{
Orientasi Kewirausahaan, Kreativitas Program Pemasaran serta Pengaruhnya terhadap Kinerja Pemasaran UMKM: Sebuah agenda Penelitian
}

\author{
Gunarso Wiwoho
}

\begin{abstract}
Abstraksi
Konsep ini bertujuan untuk menjelaskan orientasi kewirausahaan, dan kreativitas program pemasaran terhadap kinerja UMKM dengan dimediasi oleh faktor lingkungan. Proposisi umum dalam teori ini adalah bahwa kinerja pemasaran merupakan konsekuensi fit atau match atau keserasian antara dua atau lebih faktor-faktor. Dalam studi yang telah ada dinyatakan orientasi wirausaha yang digunakan berpengaruh secara signifikan terhadap peningkatan kinerja pemasaran. Hubungan ini tidak secara langsung demikian, tetapi terdapat faktor kontekstual yang ada dalam hubungan orientasi wirausaha dan kreativitas program pemasaran dengan kinerja pemasaran. Semakin fit hubungan antara orientasi wirausaha dan kreativitas program pemasaran dengan faktor kontekstual, semakin tinggi kinerja yang dicapai. Dalam suatu riset konseptual dalam upaya untuk melakukan klarifikasi mengenai konstruk orientasi wirausaha dan kreativitas program pemasaran serta hubungannya dengan kinerja pemasaran, menyatakan bahwa faktor-faktor kontekstual itu adalah faktor lingkungan. Berdasarkan telaah pustaka mengenai analisis faktor-faktor yang mempengaruhi kinerja pemasaran dengan faktor lingkungan sebagai variabel moderating, maka dikembangkan kerangka pemikiran teoritis yang mendasari konsep penelitian ini. Pada model atau kerangka pemikiran terlihat adanya pengaruh langsung antara orientasi wirausaha dan kreativitas program pemasaran terhadap kinerja pemasaran. Selain juga dilihat pengaruh moderating dari variabel lingkungan terhadap hubungan tersebut.
\end{abstract}

Kata kunci: Orientasi Kewirausahaan, Kreativitas Program Pemasaran, Faktor Lingkungan, dan Kinerja Pemasaran UMKM .

\section{Pendahuluan}

Industri merupakan salah satu aktivitas ekonomi non pertanian yang memiliki peluang besar dalam rangka perluasan lapangan pekerjaan. Mengingat hampir sebagian besar penduduk Indonesia masih tinggal di wilayah perdesaan, industri khususnya industri kecil menengah/Usaha Kecil Menengah (IKM/UKM) memiliki andil yang cukup besar dalam membuka lapangan kerja. Di negara-negara berkembang, seperti di Indonesia, UKM sering dikaitkan dengan masalah-masalah ekonomi dan sosial, seperti tingginya angka kemiskinan, besarnya jumlah pengangguran dari golongan pendidikan rendah, ketimpangan distribusi pendapatan, pembangunan tidak merata, urbanisasi dengan segala efek-efek negatifnya. 
UKM di Indonesia memiliki peran yang sangat penting terutama dalam hal penciptaan kesempatan kerja. Hal ini didasarkan pada kenyataaan bahwa jumlah angkatan kerja di Indonesia sangat melimpah mengikuti jumlah penduduk yang besar, sehingga usaha besar (UB) tidak sanggup menyerap semua pencari kerja, dan ketidak sanggupan usaha besar dalam menciptakan kesempatan kerja yang besar disebabkan karena memang pada umumnya kelompok usaha tersebut relatif padat modal, sedangkan UKM relatif padat karya. Selain itu, pada umunya usaha besar membutuhkan pekerja dengan pendidikan formal yang tinggi dan pengalaman kerja yang cukup, sedangkan UKM khususnya usaha kecil (UK), sebagian pekerjanya berpendidikan rendah. (Tulus Tambunan, 2002: 21-22). Pande raja silalahi (dalam FIGUR, 2008: 18) dalam analisisnya, menjelaskan permasalahan utama yang dihadapi industri kecil dan menengah (IKM) yaitu, sulitnya mendapatkan akses permodalan, tidak terjadi backward linkage yaitu keterkaitan yang erat antara IKM dengan industri besar, dan permasalaha IKM biasanya dirumuskan secara subjektif oleh pemerintah. Dengan adanya otonomi daerah, sesungguhnya penanganan dari permasalahan industri kecil dan menengah (IKM) dapat didesentralisasikan. Pemerintah bisa menciptakan kompetisi antar daerah dalam pemberdayaan IKM dan memberikan reward (penghargaan) bagi daerah yang berhasil.

Keberadaan UKM terbukti telah mampu menggerakkan roda perekonomian bangsa dan mengurangi jumlah pengangguran yang ada. Meski para UKM ini memiliki beberapa keterbatasan namun pada kenyataannya mereka mampu bersaing dengan perusahaan-perusahaan lain. Bahkan pada saat kondisi perekonomian memburuk dan banyak perusahaan besar yang terancam bangkrut, para UKM ini tetap mampu untuk bertahan hidup. Kenyataan ini menunjukkan kekuatan dari para UKM sebenarnya. Kekuatan para UKM ini muncul karena mereka telah mulai menerapkan visi kewirausahaannya (entrepreneurial visions) sehingga mereka mampu membawa perusahaannya tumbuh dan berkembang serta memperoleh profitabilitas yang meningkat. Sekarang ini keberhasilan UKM dalam meningkatkan pertumbuhan perusahaan masih sangat tergantung dari kemampuan wirausaha dari pemiliknya. Hanya para pemilik (owner) yang mempunyai orientasi kewirausahaan kuat yang mampu membawa peningkatan bagi perusahaan. Ketidakmampuan pemilik untuk memelihara kekuatannya dalam menghadapi tantangan yang ada justru akan berpengaruh pada turunnya kinerja dan kegagalan perusahaan (Hill dan McGowan, 1999, p.167).

Oleh karena itu, dalam menghadapi era globalisasi nantinya, 
ketergantungan perusahaan akan orientasi kewirausahaan para pemiliknya harus disertai dengan kemampuan perusahaan untuk merumuskan strateginya dan mengimplementasikan strategi tersebut dengan baik. Strategi dapat dipandang sebagai respon perusahaan, baik yang bersifat jangka pendek maupun jangka panjang, dalam menghadapi tantangan dan peluang akibat perubahan lingkungan yang terjadi. Perusahaan menerapkan strateginya dalam rangka untuk mendapatkan konsumen atau pelanggan baru dan juga untuk mengantisipasi perubahan yang terjadi. Tanpa dukungan strategi yang tepat, perusahaan akan sulit untuk bertahan di tengah persaingan (Knight, 2000, p. 13). Berawal dari sinilah, muncul tuntutan perusahaan agar mampu merumuskan strategi pemasaran dengan baik. Perusahaan perlu untuk membuat strategi-strategi pemasaran yang kreatif dan selaras dengan perubahan kondisi lingkungannya. Persaingan yang terjadi sekarang ini sangat berbeda dari persaingan pada masa lalu sehingga program-program pemasarannya pun perlu disesuaikan. Kreatifitas dalam pembuatan program pemasaran menjadi kunci kesuksesan perusahaan dalam era globalisasi.

Dari uraian di atas, dapat dikatakan bahwa keberhasilan perusahaan untuk meningkatkan kinerjanya tergantung dari dua faktor yaitu orientasi kewirausahaan dan kemampuannya dalam menyusun program-program pemasaran yang kreatif. Perusahaan atau UKM yang hanya mengandalkan jiwa kewirausahaan dari pemiliknya saja tanpa disertai dengan kemampuan untuk membuat program pemasaran yang kreatif akan sulit untuk berkembang karena mereka hanya memiliki

visi namun tidak disertai dengan strategi yang mendukungnya. Begitu pula sebaliknya, kemampuan dalam pembuatan program pemasaran yang kreatif akan sulit dilakukan jika tidak disertai oleh kemampuan untuk melihat apa tantangan yang sebenarnya sedang dihadapi. Morris dan Lewis (1995, p. 33-34) menjelaskan akan pentingnya orientasi wirausaha dan keberadaan program pemasaran sebagai satu kesatuan yang menunjang kesuksesan perusahaan terutama bagi para UKM. Pemasaran berkaitan dengan kemampuan perusahaan dalam merencanakan dan melaksanakan konsep produk, harga, promosi, dan distribusi baik barang maupun jasa sedangkan orientasi wirausaha dipandang sebagai sebuah seni dalam melihat tantangan dan peluang yang sedang dihadapi. Orientasi wirausaha berkaitan dengan jiwa atau karakteristik personal dari pemilik perusahaan dan mewarnai perusahaan tersebut. Ketiga hal tersebut yaitu orientasi wirausaha, program pemasaran, dan lingkungan tampaknya sudah menjadi satu kesatuan yang tidak terpisahkan. Ketiganya dipandang sebagai faktor yang mempengaruhi upaya perusahaan untuk meningkatkan kinerjanya. 


\section{Kinerja Pemasaran}

Kinerja pemasaran merupakan elemen penting dari kinerja perusahaan secara umum karena kinerja suatu perusahaan dapat dilihat dari kinerja pemasarannya selama ini. Kinerja pemasaran merupakan konsep untuk mengukur prestasi pemasaran suatu perusahaan. Setiap perusahaan berkepentingan untuk mengetahui prestasinya sebagai cermin dari keberhasilan usahanya dalam persaingan pasar. Slater dan Narver (1995, p. 61) menggambarkan hasil dari penerapan strategi perusahaan diantaranya berupa kepuasan konsumen, kesuksesan produk baru, peningkatan penjualan, dan profitabilitas perusahaan.

\section{Kinerja pemasaran}

adalah konstruk yang umum digunakan untuk mengukur dampak penerapan strategi perusahaan. Namun demikian, masalah pengukuran kinerja menjadi permasalahan dan perdebatan klasik karena sebagai sebuah konstruk, kinerja pemasaran bersifat multidimensional yang mana di dalamnya termuat beragam tujuan dan tipe organisasi. Oleh karena itu kinerja sebaiknya diukur dengan menggunakan berbagai kriteria pengukuran sekaligus (multiple measurement). Jika menggunakan pengukuran dengan kriteria tunggal (single measurement) maka tidak akan mampu memberikan pemahaman yang komprehensif tentang bagaimana kinerja suatu perusahaan itu sesungguhnya (Prasetya,2002,p.227).
Kinerja pemasaran juga dikatakan sebagai kemampuan organisasi untuk mentransformasikan diri dalam menghadapi tantangan dari lingkungan dengan perspektif jangka panjang (Keats et.al, 1998, p.576). Penilaian kinerja menjadi bagian dari upaya perusahaan dalam melihat kesesuaian strategi yang diterapkannya dalam menghadapi perubahanperubahan lingkungan. Lingkungan memang telah menjadi bagian penting dari perusahaan dan merupakan hal yang sulit untuk dirubah oleh perusahaan tersebut. Perusahaan hanya dapat mengenalinya untuk kemudian mengelola dengan baik sehingga dapat memberi manfaat bagi perusahaan. Pengenalan lingkungan yang baik akan memberi dampak pada mutu strategi yang dihasilkan yang selanjutnya akan berdampak pada kinerja pemasaran..

Kinerja pemasaran merupakan konstruk yang sering digunakan untuk mengukur dampak strategi-strategi dan orientasi yang diterapkan perusahaan. Strategi pemasaran selalu diarahkan untuk menghasilkan kinerja pemasaran (seperti volume penjualan dan tingkat pertumbuhan penjualan) yang baik dan juga kinerja keuangan yang baik. Ukuran yang sebaiknya digunakan adalah ukuran yang bersifat activitybased measure yang dapat menjelaskan aktivitas-aktivitas pemasaran yang menghasilkan kinerja-kinerja pemasaran misalnya lebih baik untuk menggunakan ukuran jumlah unit yang terjual atau dihasilkan dari pada hanya 
menggunakan nilai rupiah dari penjualan (Ferdinand, 2000, p.116) .

\section{Orientasi Wirausaha}

Pengertian orientasi wirausaha berbeda dengan pengertian kewirausahaan secara umum. Lumpkin dan Dess (1996, p. 136) dalam usahanya untuk mengklarifikasi kebingungan dalam istilah, memberikan perbedaan yang jelas antara orientasi wirausaha (entrepreneurial orientation) dengan kewirausahaan (entrepreneurship). Kewirausahaan adalah new entry yang dapat dilakukan dengan memasuki pasar yang tetap ataupun pasar yang baru dengan produk atau jasa yang telah ada ataupun yang baru ataupun meluncurkan perusahaan baru. Sedangkan orientasi wirausaha didefinisikan sebagai penggambaran bagaimana new entry dilaksanakan oleh perusahaan. Orientasi wirausaha digambarkan oleh proses, praktek dan aktivitas pembuatan keputusan yang mendorong new entry. Jadi kewirausahaan dapat dianggap sebagai produk dari orientasi wirausaha. Proses, praktek dan aktivitas pembuatan keputusan (orientasi wirausaha) menghasilkan new entry (kewirausahaan). Orientasi wirausaha mencerminkan kecenderungan perusahaan untuk terlibat dalam perilaku inovatif, berani mengambil resiko dan proaktif untuk mengalahkan pesaing. Perusahaan yang terlibat dalam perilaku semacam ini dapat secara efektif berkembang atau meningkatkan kinerja dan daya saing perusahaan.

$$
\text { Knight (2000, p. }
$$

menjelaskan bahwa orientasi wirausaha berkaitan dengan pencarian peluang, keberanian mengambil resiko, dan keputusan untuk bertindak dari para pimpinan organisasi. Orientasi wirausaha akan menjadi sistem nilai bagi perusahaan dan akan menentukan gerak atau strategi perusahaan. Perusahaan yang memiliki nilai untuk terus mencari peluang akan bergerak terus untuk mencoba memasuki pasar baru guna mengambil peluang yang ada disana.

Begitu pula jika perusahaan mendukung keberanian untuk mengambil resiko maka mereka akan berani untuk mencoba hal atau strategi baru atau mencoba bisnis baru yang sekiranya berpeluang untuk meningkatkan kinerja perusahaan. Karakter-karakter dari seorang wirausahawan yang berhasil ditransfer ke dalam organisasi akan mewarnai organisasi tersebut sehingga berpeluang untuk meningkatkan penjualan produk perusahaan tersebut.

Orientasi wirausaha diukur melalui lima dimensi yaitu otonomi, inovasi, berani mengambil resiko, bertindak proaktif, dan agresif dalam bersaing (Lumpkin dan Dess, 1996, p.138 - 149). Otonomi adalah tindakan individu atau tim yang membawa ideide atau visi baru dan berupaya untuk mencapainya. Inovasi diartikan sebagai kecenderungan perusahaan untuk membolehkan dan mendukung ide-ide baru, percobaan, dan proses kreatif 
yang mungkin berupa produk baru, pelayanan baru, atau proses teknologi. Berani mengambil resiko adalah keberanian pelaku usaha untuk mengambil resiko atas segala keputusan yang diambilnya. Bertindak proaktif adalah keberanian pelaku usaha untuk melakukan tindakan guna menghadapi permasalahan di depan, kebutuhan, atau perubahan yang mungkin terjadi. Agresif

dalam bersaing merupakan keberanian pelaku usaha untuk membuka pasar baru dan mencoba untuk lebih sukses lagi. Kelima dimensi ini menjadi satu kesatuan dalam diri wirausahawan dan kemudian menjadi panduan tindakan bagi wirausahawan tersebut. Melalui orientasi wirausaha, pimpinan akan mampu membawa perusahaan mencapai kinerja yang lebih baik. Hasil penelitian membuktikan bahwa orientasi wirausaha berpengaruh positif terhadap kinerja pemasaran.

\section{Kreativitas Program Pemasaran}

Proses pengembangan strategi pemasaran (Marketing Strategy Making, MSM- Process) merupakan salah satu bidang kajian penting dalam studi manajemen pemasaran. Hal ini penting karena paradigma sistem menyatakan bahwa kinerja sebuah strategi tidak semata-mata ditentukan oleh bagaimana implementasi strategi dan evaluasi strategi dilakukan secara terus menerus, tetapi juga ditentukan oleh seberapa baik proses yang menyertai pengembangan strategi itu. Sesuai dengan paradigma sistem itu, kinerja sebuah strategi akan ditentukan oleh seberapa baik penyiapan dan penyediaan input serta sumberdaya untuk membentuk konten sebuah strategi, serta input dan sumberdaya untuk menjalankan strategi. Kinerja sebuah strategi akan ditentukan pula oleh proses yang dilewati dalam menyajikan sebuah strategi, serta berwujud sebagai keluaran dari sebuah strategi yang telah diformulasikan melalui proses dan masukan yang baik, dan karena itu dapat menghasilkan sebuah strategi yang bermutu (Ferdinand, 2002, p. 1).

Penyusunan strategi pemasaran melibatkan penentuan kekuatan, arah tujuan dan interaksi dari kekuatan strategik tersebut. Tujuan dari pengembangan strategi pemasaran adalah membangun, menjaga, dan mempertahankan keunggulan bersaing. Para peneliti banyak yang memahami penyusunan strategi adalah sebagai proses analitis yang tersusun. Pada umumnya, pengembangan strategi pemasaran memiliki karakteristik sebagai berikut (Adhinugroho, 2002, p. 277):

a. Secara khusus berkaitan dengan penentuan cara bagaimana perusahaan mampu unggul dalam persaingan, dengan memanfaatkan kekuatannya untuk memberi nilai lebih kepada pelanggannya dari waktu ke waktu.

b. Merupakan suatu proses yang kompleks dimana biasanya melibatkan pengambilan keputusan yang kompleks pula oleh para manajer dan memerlukan analisis yang komprehensif tentang 
perubahan lingkungan maupun suatu perpaduan dari informasi yang bermanfaat.

c. Memerlukan banyak informasi strategik yang relevan dan juga pengetahuan yang luas.

d. Melibatkan ketidakpastian dan kerancuan yang tinggi.

e. Melibatkan pengalaman, intuisi dan dugaan dari para manajer.

Berbagai karakteristik tersebut membuktikan pembuatan program pemasaran memerlukan kreativitas dalam melihat lingkungan yang ada. Pihak perusahaan tidak bisa hanya mengandalkan data internal perusahaan saja tetapi juga perlu mencari data-data pasar lainnya dan kemampuan manajer untuk melihat peluang dan ancaman yang timbul di sana. Dengan adanya keselarasan antara program pemasaran dengan kondisi lingkungan maka perusahaan akan mampu bersaing dengan perusahaan lain dan mereka juga mampu untuk meningkatkan kinerja pemasarannya.

Mardiyanto (2002, p. 63) menjelaskan bahwa kreativitas program pemasaran adalah pengembangan terhadap implementasi atau penerapan strategi yang dilakukan dalam pasar (bentuk perubahan), yang menunjukkan sebuah perbedaan yang berarti dari praktek pemasaran. Kreativitas program pemasaran adalah suatu hal baru yang telah banyak digunakan untuk menggambarkan kreativitas dalam bidang periklanan. Kreativitas merupakan usaha pemecahan masalah bisnis yang dihadapi setiap hari. Proses kreativitas berakhir ketika dihasilkan sebuah produk baru, ide baru, strategi-strategi baru guna menyiasati perubahan-perubahan yang ada. Melalui kreativitas program pemasaran, perusahaan akan memperolah sudut pandang baru yang bisa dipakai untuk menghadapi peluang dan ancaman di depan. Kreativitas memerlukan pengembangan yang lebih baru dan alternatif yang lebih agresif sehingga dapat di ibaratkan seperti sebuah motor penggerak yang menawarkan proses pembelajaran baru dan potensial untuk merubah perilaku-perilaku dalam organisasi.

Seiring dengan makin meningkatnya persaingan, peranan pemasaran sebagai bagian penting dari perusahaan tidak dapat diabaikan. Perusahaan perlu untuk terus menyesuaikan program pemasarannya dengan berbagai perubahan yang terjadi dalam lingkungannya. Dalam hal ini, kreativitas program pemasaran menjadi kunci untuk menghadapi persaingan. Menurut Andrew dan Smith (1996, p. 88) kreativitas merupakan usaha pemecahan masalah bisnis yang dihadapi setiap hari. Kreativitas muncul karena adanya perubahan yang terjadi. Artinya, perubahan kondisi dalam lingkungan bisnis membuat perusahaan harus memikirkan cara-cara baru guna menyesuaikan dirinya dan untuk kemudian bersiap untuk bersaing dengan perusahaan lain. Kreativitas muncul sebagai bentuk pengembangan alternatif 
yang lebih baru dan mungkin lebih radikal dari strategi sebelumnya.

Hasil penelitian Menon dkk (1999, p.31) menemukan bahwa kreativitas strategi pemasaran berhubungan secara positif dengan kinerja pasar. Sedang kinerja pasar sendiri merupakan elemen dari kinerja pemasaran secara umum. Kilroy (1999, p.369) menjelaskan ada tiga indikator yang dapat dipakai untuk mengukur kreativitas yaitu pencarian informasi, diskusi program, dan kesesuaian program. Pencarian informasi terkait dengan upaya perusahaan untuk mengenali kondisi lingkungannya. Diskusi program terkait dengan upaya perusahaan untuk bertukar pandangan atas program-program yang ada. Kesesuaian program terkait dengan kesesuaian program dengan kondisi lingkungan. Kreativitas dalam pembuatan program pemasaran akan memberikan suatu mekanisme bagi perusahaan untuk melakukan diferensiasi sehingga dapat digunakan sebagai senjata dalam meningkatkan kinerja pemasaran. Selama perusahaan masih menggunakan program pemasaran yang lama dan tidak melakukan penyesuaian dengan perubahan kondisi yang terjadi maka perusahaan akan sulit bersaing karena 'selera' dari para konsumen sudah berubah. Hal ini menjadi dasar bagi perlunya suatu perusahaan untuk mencari program-program

pemasaran yang kreatif dan dapat digunakan sebagai media menarik guna memperoleh pelanggan.

\section{Faktor Lingkungan}

Lingkungan persaingan selalu dianggap sebagai faktor penghambat tingkat pertumbuhan industri. Elemen lingkungan persaingan seharusnya dipelajari lebih lanjut karena kegagalan industri di dalam mencapai pertumbuhan penjualan bersumber dari ketidakmampuan manajemen dalam menganalisa perubahan yang terjadi di lingkungan persaingan industri. Pengetahuan yang lebih luas tentang lingkungan pemasaran akan meningkatkan kemampuan pihak manajemen untuk menganalisa data yang diterima dan memilih data yang diperlukan serta menentukan tujuan perusahaan sebagai respon terhadap perubahan kondisi lingkungan (Menon dkk, 1999, p.25).

Kondisi lingkungan eksternal diketahui memiliki peranan yang besar dalam mempengaruhi pengambilan keputusan manajerial, proses, dan struktur organisasi sehingga pemantauan terhadap lingkungan eksternal sangat diperlukan. Namun demikian analisis terhadap lingkungan eksternal sangat sulit dilakukan karena lingkungan eksternal sangat kompleks dan saling terkait satu dengan lainnya.

Dinamika lingkungan lebih menekankan pada perubahan-perubahan yang cepat, sulit diprediksi, dan tidak direncanakan sebelumya. Perusahaan yang beroperasi dalam pasar yang berubah-ubah dengan cepat dituntut untuk senantiasa memodifikasi produk dan pelayanannya sebagai upaya untuk memenuhi perubahan pasar secara memuaskan. 
Dalam kondisi lingkungan yang berubah cepat ini, keunggulan bersaing perusahaan ditentukan oleh kreativitas dan inovasi yang dapat memuaskan pelanggan secara lebih baik dibanding pesaing.

Oleh karena itu, dalam kondisi lingkungan pasar yang dinamis, fokus pada pelanggan dan pesaing menjadi satu kewajiban yang tidak dapat dihindari perusahaan (Prasetya, 2002, p. 223 - 224). Hadjimanolis (2000, p.238) menjelaskan bahwa intensitas kompetisi dan persaingan lingkungan merupakan ukuran pasar untuk berinovasi. Pada saat para pesaing mengeluarkan strategi baru sehingga mereka memiliki kesempatan untuk berkembang di pasar maka intensitas persaingan yang terjadi akan semakin tinggi. Mereka memiliki bekal yang cukup kuat untuk bersaing. Saat inilah perusahaan perlu melakukan inovasi guna mengimbangi perubahan strategi yang dilakukan pesaing. Perusahaan yang tidak memiliki sumber daya cukup guna merespon perubahan biasanya akan tertinggal dari pesaingnya. Beliau juga mengemukakan bahwa perusahaan yang menggunakan lebih banyak sumber-sumber informasi teknologi cenderung lebih inovatif dibandingkan perusahaan yang tidak memanfaatkan informasi teknologi. Keberadaan teknologi informasi dapat dipakai sebagai 'jendela' untuk melihat peluang dan ancaman yang ada di lingkungan. Dengan informasi teknologi sekaligus perusahaan akan dapat mengukur kekuatan yang dimilikinya jika dibandingkan dengan para pesaing.

$$
\text { Luo }
$$

(1999,

mengkonsepkan dinamika atau perubahan sebagai derajat perubahan dan ketidakstabilan lingkungan yang sulit diramalkan. Lingkungan bisnis yang selalu berubah bisa terjadi karena perubahan peraturan, teknologi, permintaan konsumen dan atau standar kompetisi. Penelitian yang dilakukan oleh Calantone (1994, p.145) juga berhasil membuktikan adanya pengaruh antara inovasi dengan kesuksesan produk baru.

Perusahaan yang berani untuk mengambil resiko guna melakukan inovasi akan berhasil dalam menciptakan ide-ide baru dan produkproduk baru yang disukai pasar. Hal ini dikarenakan dalam mencari sebuah terobosan atau inovasi, perusahaan akan mencari dari berbagai sumber tentang perubahan kondisi pasar yang terjadi. Perusahaan seharusnya akan mendapatkan informasi tentang produk seperti apa yang diinginkan oleh konsumen. Dari informasi tersebut, perusahaan dengan segala kemampuannya akan menciptakan produk baru yang sesuai dengan tuntutan konsumen dan sebagai akibatnya produk tersebut akan diminati oleh konsumen. Bagi perusahaan kondisi ini akan mendatangkan keuntungan berupa terbelinya produk sehingga secara langsung akan meningkatkan kinerja pemasarannya. Hal ini menjadi dasar untuk melihat hubungan antara kreativitas program pemasaran dan 
lingkungan bagi peningkatan kinerja pemasaran.

Penelitian yang dilakukan oleh Frese dkk (2002, p. 271 - 274) berhasil membuktikan adanya kebutuhan perusahaan untuk berorientasi wirausaha pada saat kondisi lingkungannya mengalami masa yang sulit. Orientasi wirausaha tidak terlalu

berpengaruh bagi perusahaan ketika berada dalam kondisi lingkungan yang biasa saja atau tanpa adanya perubahan atau persaingan yang tajam. Hal ini dikarenakan, karakteristik dari orientasi wirausaha merupakan pendobrak atau pencari jalan baru guna membawa perusahaan mencari jalan keluar yang lebih baik ketika kondisi makin memburuk. Sebaliknya ketika kondisi lingkungan relatif sama maka orientasi kewirausahaan tidak terlalu berpengaruh. Perusahaan cenderung melakukan strategi yang sebelumnya telah dilakukan dengan sedikit perubahan-perubahan guna penyesuian.

\section{Penelitian Terdahulu}

Pengembangan model penelitian harus didasarkan atas penelitian-penelitian terdahulu. Adapun beberapa penelitian terdahulu yang digunakan sebagai dasar acuan dalam pembentukan model dan hipotesis penelitian ini dapat dilihat pada tabel di bawah ini.

Tabel 2.1

\section{Penelitian Terdahulu}

\begin{tabular}{|c|c|c|c|}
\hline Pengarang & Judul Penelitian & Alat Analisis & Hasil \\
\hline $\begin{array}{l}\text { Menon, Anil, } \\
\text { Sundar G. } \\
\text { Bharadwaj, Phani } \\
\text { Tej. Adidam, } \\
\text { Steven W. Edison } \\
\text { (1999) }\end{array}$ & $\begin{array}{l}\text { Antecedents and } \\
\text { concequences of } \\
\text { marketing strategy } \\
\text { making : a model } \\
\text { and a test (Journal } \\
\text { of Marketing, Vol. } \\
63 \text { ) }\end{array}$ & Analisis SWOT & $\begin{array}{l}\text { Adanya pengaruh } \\
\text { yang signifikan dari } \\
\text { kreativitas strategi } \\
\text { pemasaran terhadap } \\
\text { kinerja pemasaran. } \\
\text { - } \\
\text { Persaingan lingkungan } \\
\text { memiliki pengaruh } \\
\text { terhadap kreativitas } \\
\text { strategi pemasaran dan }\end{array}$ \\
\hline
\end{tabular}




\begin{tabular}{|c|c|c|c|}
\hline $\begin{array}{l}\text { Han, Jin K., } \\
\text { Namwoon Kim, } \\
\text { Rajendra K. } \\
\text { Srivastava (1998) }\end{array}$ & $\begin{array}{l}\text { Market orientation } \\
\text { and organizational } \\
\text { performance : Is } \\
\text { innovation a } \\
\text { missing link? } \\
\text { (Journal of } \\
\text { Marketing, Vol. } \\
\text { 62) }\end{array}$ & Analisis SEM & $\begin{array}{l}\text { Bahwa kondisi } \\
\text { lingkungan } \\
\text { (perubahan pasar dan } \\
\text { perubahan teknologi) } \\
\text { sangat berpengaruh } \\
\text { terhadap inovasi } \\
\text { perusahaan sehingga } \\
\text { bisa meningkatkan } \\
\text { kinerja perusahaan. }\end{array}$ \\
\hline $\begin{array}{l}\text { Andrews, Jonlee } \\
\text { dan Daniel C. } \\
\text { Smith (1996) }\end{array}$ & $\begin{array}{l}\text { In search of the } \\
\text { marketing } \\
\text { imagination: } \\
\text { factors affecting } \\
\text { the creativity of } \\
\text { marketing } \\
\text { programs for } \\
\text { mature products } \\
\text { (Journal of } \\
\text { Marketing } \\
\text { Research, Vol. } \\
\text { XXXIII) }\end{array}$ & Analisa faktor & $\begin{array}{l}\text { Faktor motivasi, } \\
\text { faktor situasi dan } \\
\text { masukan pemecahan } \\
\text { masalah berpengaruh } \\
\text { terhadap kreativitas } \\
\text { program pemasaran. } \\
\text { Sedangkan faktor } \\
\text { situasional secara } \\
\text { umum kurang } \\
\text { berperan dalam } \\
\text { kreativitas program } \\
\text { pemasaran. }\end{array}$ \\
\hline $\begin{array}{l}\text { Mardiyanto, Agus, } \\
(2002)\end{array}$ & $\begin{array}{l}\text { Studi mengenai } \\
\text { kreativitas } \\
\text { program dan } \\
\text { kinerja pemasaran } \\
\text { (Jurnal Sains } \\
\text { Pemasaran } \\
\text { Indonesia, Mei } \\
\text { 2002) }\end{array}$ & $\begin{array}{l}\text { Confirmatory } \\
\text { Factor }\end{array}$ & $\begin{array}{l}\text { Kreativitas program } \\
\text { pemasaran } \\
\text { dipengaruhi oleh } \\
\text { motivasi internal, } \\
\text { penghargaan, } \\
\text { lingkungan kerja, } \\
\text { masukan pemecahan } \\
\text { masalah dan kesediaan }\end{array}$ \\
\hline
\end{tabular}




\begin{tabular}{|c|c|c|c|}
\hline $\begin{array}{l}\text { Fillis, Ian dan } \\
\text { Andrew } \\
\text { McAuley (2000) }\end{array}$ & $\begin{array}{l}\text { Modelling and } \\
\text { measuring } \\
\text { creativity at the } \\
\text { interface (Journal } \\
\text { of Marketing } \\
\text { Theory and } \\
\text { Practise, Spring, } \\
\text { p.8-17) }\end{array}$ & Analisa Faktor & $\begin{array}{l}\text { - Kesuksesan } \\
\text { kreativitas pada } \\
\text { sebuah perusahaan } \\
\text { kecil tergantung pada } \\
\text { perhatian dari } \\
\text { manajer. Gaya hidup } \\
\text { adalah kunci dari } \\
\text { motivasi, dipunyai } \\
\text { dan dipercayai oleh } \\
\text { manajer untuk bisa } \\
\text { menumbuhkan } \\
\text { perusahaan. } \\
\text { Kreativitas juga } \\
\text { mengekspresikan } \\
\text { kualitas } \\
\text { kepemimpinan dari } \\
\text { manajer. Kreativitas } \\
\text { adalah bagian dari } \\
\text { manusia untuk } \\
\text { membangun sebuah } \\
\text { bisnis. } \\
\end{array}$ \\
\hline $\begin{array}{l}\text { Lee, Jangwoo dan } \\
\text { Danny Miller, } 1996\end{array}$ & $\begin{array}{l}\text { Strategy, } \\
\text { Environment, and } \\
\text { Performance in } \\
\text { Two } \\
\text { Technological } \\
\text { Contexts : } \\
\text { Contingency } \\
\text { Theory in Korea", } \\
\text { Organization } \\
\end{array}$ & Anova & $\begin{array}{l}\text { Kesesuaian antara } \\
\text { strategi dan } \\
\text { lingkungan akan } \\
\text { bepengaruh positif } \\
\text { terhadap kinerja } \\
\text { organisasi }\end{array}$ \\
\hline
\end{tabular}




\begin{tabular}{|c|c|c|c|}
\hline $\begin{array}{l}\text { Lumpkin G.T dan } \\
\text { Dess G.G (1996) }\end{array}$ & $\begin{array}{l}\text { Clarifying the } \\
\text { entrepreneurial } \\
\text { orientation } \\
\text { construct and } \\
\text { linking it to } \\
\text { performance } \\
\text { (Academy of } \\
\text { Management } \\
\text { Review, Vol. 21) }\end{array}$ & $\begin{array}{l}\text { Tidak dilakukan } \\
\text { analisis. Lumpkin } \\
\text { dan Dess hanya } \\
\text { mencoba untuk } \\
\text { menjelaskan sifat } \\
\text { konstruk orientasi } \\
\text { wirausaha dan } \\
\text { memberikan } \\
\text { model alternatif } \\
\text { untuk meneliti } \\
\text { hubungan antara } \\
\text { orientasi } \\
\text { wirausaha dengan } \\
\text { kinerja. }\end{array}$ & $\begin{array}{l}\text { - Model Lumpkin dan } \\
\text { Dess } \\
\text { mengindikasikan } \\
\text { bahwa faktor } \\
\text { lingkungan dan faktor } \\
\text { organisasi secara } \\
\text { moderat } \\
\text { mempengaruhi } \\
\text { hubungan antara } \\
\text { orientasi wirausaha } \\
\text { dan kinerja } \\
\text { perusahaan. }\end{array}$ \\
\hline $\begin{array}{l}\text { Frese, Brantjes dan } \\
\text { Hoorn (2002) }\end{array}$ & $\begin{array}{l}\text { Psychological } \\
\text { success factors of } \\
\text { small scale } \\
\text { business in } \\
\text { Namibia : the roles } \\
\text { of strategy } \\
\text { process, } \\
\text { entrepreneurial } \\
\text { orientation and the } \\
\text { environment } \\
\text { (Journal of } \\
\text { developmental } \\
\text { entrepreneurship, } \\
\text { Vol. 7) }\end{array}$ & Analisis regresi & $\begin{array}{l}\text { Dalam kondisi } \\
\text { lingkungan yang } \\
\text { memburuk, orientasi } \\
\text { wirausaha } \\
\text { berpengaruh positif } \\
\text { terhadap sukses } \\
\text { perusahaan }\end{array}$ \\
\hline
\end{tabular}

Sumber : dikembangkan untuk penelitian ini 


\section{Pengembangan Model}

Proposisi umum dalam teori ini adalah bahwa kinerja pemasaran merupakan konsekuensi fit atau match atau keserasian antara dua atau lebih faktor-faktor. Dalam studi yang telah ada dinyatakan orientasi wirausaha yang digunakan berpengaruh secara signifikan terhadap peningkatan kinerja pemasaran (Dess, Lumpkin dan Covin, 1997). Hubungan ini tidak secara langsung demikian, tetapi terdapat faktor kontekstual yang ada dalam hubungan orientasi wirausaha dan kreativitas program pemasaran dengan kinerja pemasaran. Semakin fit hubungan antara orientasi wirausaha dan kreativitas program pemasaran dengan faktor kontekstual, semakin tinggi kinerja yang dicapai. Dalam suatu riset konseptual dalam upaya untuk melakukan klarifikasi mengenai konstruk orientasi wirausaha dan kreativitas program pemasaran serta hubungannya dengan kinerja pemasaran, Lumpkin dan Dess (1996) menyatakan bahwa faktor-faktor kontekstual itu adalah faktor lingkungan.Berdasarkan telaah pustaka mengenai analisis faktor-faktor yang mempengaruhi kinerja pemasaran dengan faktor lingkungan sebagai variabel moderating, maka dikembangkan kerangka pemikiran teoritis yang mendasari penelitian ini. Pada model atau kerangka pemikiran terlihat adanya pengaruh langsung antara orientasi wirausaha dan kreativitas program pemasaran terhadap kinerja pemasaran. Selain juga dilihat pengaruh moderating dari variabel lingkungan terhadap hubungan tersebut. Selanjutnya gambaran model atau kerangka pemikiran penelitian ini dapat dilihat pada gambar 1 .

Gambar 1.

Model Teoritikal Dasar

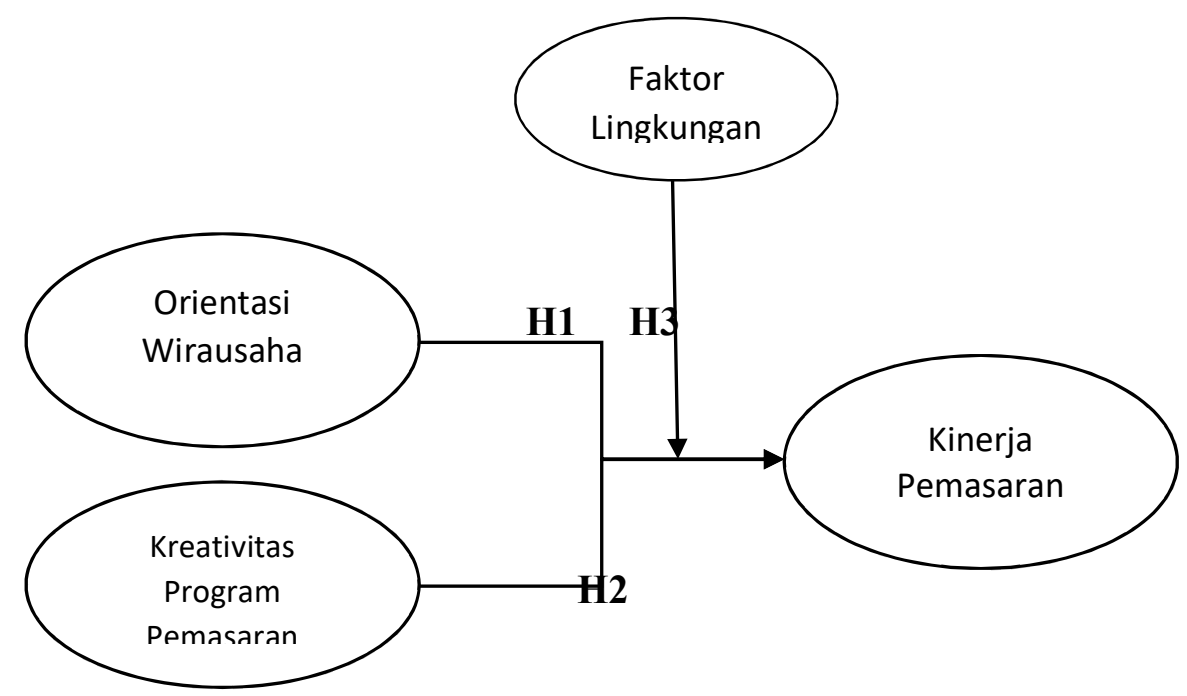

Sumber : dikembangkan untuk penelitian ini 


\section{Hipotesis Penelitian}

Berdasarkan telaah pustaka dan kerangka pemikiran teoritis maka hipotesis yang diajukan pada penelitian ini adalah :

H1 : Orientasi wirausaha berpengaruh positif terhadap kinerja pemasaran.

Hubungan antara orientasi wirausaha terhadap kinerja pemasaran didasari atas penelitian yang dilakukan oleh Lumpkin dan Dess (1996) dan Frese dkk (2002) yang berhasil membuktikan bahwa orientasi wirausaha berpengaruh positif terhadap kinerja pemasaran.

$\mathrm{H} 2$ : Kreativitas program pemasaran berpengaruh positif terhadap kinerja pemasaran.

Hubungan antara kreativitas program pemasaran terhadap kinerja pemasaran didasari atas penelitian Andrew dan Smith (1996) dan Menon dkk (1999) yang berhasil membuktikan bahwa program pemasaran yang tepat berpengaruh positif terhadap kinerja pemasaran.

H3 : Faktor lingkungan yang memoderasi orientasi wirausaha dan kreativitas program pemasaran memiliki pengaruh positif terhadap kinerja pemasaran.

Hubungan antara orientasi wirausaha dan kreativitas program pemasaran terhadap kinerja pemasaran yang dimoderasi oleh faktor lingkungan didasari atas penelitian Frese dkk (2002), Menon dkk (1999), dan Han dkk (1998) yang berhasil membuktikan bahwa pengaruh keberadaan orientasi wirausaha dan program pemasaran terhadap kinerja pemasaran akan semakin kuat ketika kondisi lingkungan mengalami perubahan yang dinamis.

\section{Daftar Pustaka}

Adhinugroho, Hendrar, 2002, "Sistem Informasi Pemasaran dan Environmental Scanning Pengaruhnya Terhadap Kualitas Layanan, Keunggulan Bersaing, dan Pertumbuhan Pelanggan, Jurnal Sains Pemasaran Indonesia, Vol. 1, No. 3, p. 275 -291

Andrews, Jonlee and Daniel C. Smith, 1996, "In Search of the Marketing Imagination: Factors Affecting the Creativity of Marketing Programs for Mature Products", Journal of Marketing Research, Vol. 33, p. 87174.

Calantone, Roger J et. al, 1994, Examining the Relationship between Degree of Innovation and New Product Success", Journal of Business Research, Vol. 30, p. 143148.

Cooper, D. R dan Emory, W, 1995,

"Business Research Method", Fifth Edition, Irwin, USA.

Dess, G.G., G.T. Lumpkin, dan J.G. Covin, 1997, "Entrepreneurial Strategy Making and Firm Performance: Test of Contingency and Configurational Models", Strategic Management Journal, Vol.18, No. 9, p. 677 - 695 Ferdinand, Augusty, 2000, "Manajemen

Pemasaran : Sebuah Pendekatan Stratejik", Program Magister

Manajemen Universitas Diponegoro,

Semarang.

Ferdinand, Augusty, 2002, "Marketing Strategy Making: Proses dan Agenda

Penelitian", Jurnal Sains Pemasaran

Indonesia, Vol.1 No, 1, p. 1-22. 
Fillis, Ian and Andrew McAuley, 2000, "Modelling and Measuring Creativity at the Interface", Journal of Marketing Theory and Practice, Spring, p. 8-17.

Frese, Brantjes dan Hoorn, 2002, "Psychological Success Factors of Small Scale Businesses in Namibia : The Roles of Strategy Process, Entrepreneurial Orientation and The Environment", Journal of Developmental Entrepreneurship, Vol. 7, No. 3.

Ghozali, I, 2002, “Aplikasi Analisis Multivariate dengan Program SPSS", Badan Penerbit Universitas Diponegoro.

Hadjimanolis, Athanasios, 2000, “An Investigation of Innovation Antecedents in Small Firms in the Context of Small Developing Country", R\&D Management, Vol. 30, p. 235-245.

Han, Jin, K., Kim, Namwoon dan Srivastava, Rajendra K, 1998, "Market Orientation and Organizational Performance: Is Innovation a Missing Link?", Journal of Marketing, Vol. 62, p. $30-45$

Hill, Jimmy dan Pauric McGowan, 1999, "A qualitative approach to developing small firm marketing planning competencies", Qualitative Market Research: An International Journal, Vol.2, No.3, p.167-175

Keats BW dan Hitt MA, 1998, “A Causal Model of Linkages Among Environmental Dimentions, Macro
Organizational Characteristic and Performance" Academy of Management Journal, Vol. 31, p.570-598.

Knight, Gary, 2000, "Entrepreneurship and Marketing Strategy: the SME Under

Globalization", Journal of International Marketing, Vol.8, No.2, p.12 -32

Lee, Jangwoo dan Danny Miller, 1996, "Strategy, Environment, and Performance in Two Technological Contexts : Contingency Theory in Korea", Organization Studies, $17 / 5$, p. $729-750$

Lumpkin, G. T., dan Dess, G. G., 1996, "Clarifying the Entrepreneurial Orientation Construct and Linking it to Performance", Academy of Management Review, Vol. 21 (1), p. 135-172.

Luo, Yadong, 1999, "EnvironmentStrategy-Performance Relation in Small Business in China : A Case of Township and Village Enterprises in Southern China", Journal of Small Business Management, January, $p$. 37-52.Morris, Michael H. dan Pamela S. Lewis, 1995, "Determinants of Entrepreneurial Activity Implications for Marketing", European Journal of Marketing, Vol. 29 No. 7, 1995, p. 31-48.

Mardiyanto, Agus, 2002, "Studi Mengenai Kreativitas Program dan Kinerja Pemasaran", Jurnal Sains Pemasaran Indonesia, Program Magister Manajemen Fakultas Ekonomi Universitas Diponegoro, p. 57-78. 
Menon, Anil, Sundar G. Bharadwaj, Phani Tej Adidam dan Steven W. Edison, 1999, "Antecedents and Concequences of Marketing Strategy Making : A Model and A Test", Journal of Marketing, Vol. 63, p.18-40.

Nasir, M., dan Agus Handoyo, 2003, "Pengaruh Orientasi Wirausaha Terhadap Kinerja Perusahaan Kecil 444. dengan Lingkungan dan Strategi sebagai Variabel Moderat (Studi Kasus Pada Industri Aneka di Kota Semarang”, Jurnal Bisnis Strategi, Vol.12, Desember, p. $89-104$.

N, Venkatraman, 1989, "The Conceptual of Fit in Strategy Research: Toward Verbal and Statistical Correspondence", Academy of Management Review, Vol 3, p. 42 
Prasetya, Dicky Imam, 2002, "Lingkungan Eksternal, Faktor Internal, dan Orientasi Pasar Pengaruhnya terhadap kinerja Pemasaran", Jurnal Sains Pemasaran Indonesia, Vol. 1, No. 3, p. 219 -240.

Riyanto, Bambang, 2001, "Alternative Approach to Examining A Contingency Model In Accounting Research : A Comparison", Jurnal Riset Akuntansi, Manajemen, Ekonomi, Vol. 1, No. 1, Februari, p. 1 - 12.

Slater, F. Stanley dan John C. Narver, 1995, "Market Orientation and the Learning Organization”, Journal of Marketing, Vol.59.

Song, X. Michael, Mark E. Parry, 1997, "A Cross National Comparative Study of New Product Development Processess : Japan and The United States", Journal of Marketing, Vol. 61, April, p. 1-18.

Sugiyono, 1999, "Metode Penelitian Bisnis", Alfabeta Bandung.

Voss GB dan Voss ZG, 2000, "Strategic Orientation and Firm Performance in an Artistic Environment”, Journal of Marketing, Vol. 64, p. 67-83. 